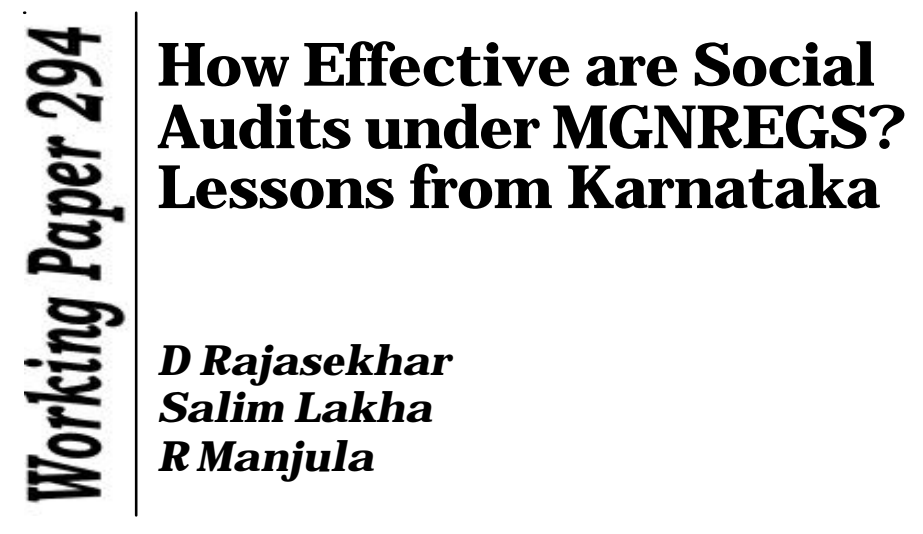




\section{ISBN 978-81-7791-150-3}

\section{(C) 2013, Copyright Reserved}

The Institute for Social and Economic Change,

Bangalore

Institute for Social and Economic Change (ISEC) is engaged in interdisciplinary research in analytical and applied areas of the social sciences, encompassing diverse aspects of development. ISEC works with central, state and local governments as well as international agencies by undertaking systematic studies of resource potential, identifying factors influencing growth and examining measures for reducing poverty. The thrust areas of research include state and local economic policies, issues relating to sociological and demographic transition, environmental issues and fiscal, administrative and political decentralization and governance. It pursues fruitful contacts with other institutions and scholars devoted to social science research through collaborative research programmes, seminars, etc.

The Working Paper Series provides an opportunity for ISEC faculty, visiting fellows and PhD scholars to discuss their ideas and research work before publication and to get feedback from their peer group. Papers selected for publication in the series present empirical analyses and generally deal with wider issues of public policy at a sectoral, regional or national level. These working papers undergo review but typically do not present final research results, and constitute works in progress. 


\title{
HOW EFFECTIVE ARE SOCIAL AUDITS UNDER MGNREGS? LESSONS FROM KARNATAKA
}

\author{
D Rajasekhar ${ }^{*}$, Salim Lakha ${ }^{* *}$ and R Manjula***
}

\begin{abstract}
This case study on social audits under MGNREGS in Karnataka aims to provide suggestions on how to improve the design and implementation of social audits in the state. With the help of the primary data collected from five grama panchayats in Chitradurga district, the paper argues that although the documentary evidence shows that social audits are conducted they do not fulfil the main objective of engaging the beneficiaries of the scheme and making the scheme effective Social audit process is compromised by the influencewielded by village elites which results in the exclusion of poor labourers for whom the scheme is primarily meant. The social audit process could be made more participatory by ensuring that it is conducted in an impartial manner.
\end{abstract}

\section{Introduction}

Social Audit is recognized as an important accountability tool in the development sector because it is argued that it contributes to transparency and effective governance (CAG 2010). The mandatory requirement for social audit under Mahatma Gandhi National Rural Employment Guarantee Scheme (MGNREGS) ${ }^{1}$, which was launched in 2005 by the Government of India (Gol), is an innovative measure aimed at ensuring accountability from those involved in the implementation of the scheme. What is particularly significant is that social audit under MGNREGS is to be conducted by the beneficiaries of the scheme. While the scheme is to be implemented by Gram Panchayats (GPs) or Village Councils, it is the members of Gram Sabhas (Village Assemblies) comprising of ordinary villagers who are responsible for conducting the audits.

Though social audits are conducted in many different contexts, under MGNREGS an audit involves the "checking and verification" of the implementation of the scheme by "primary stakeholders" which include the beneficiaries (Singh and Rajakutty 2007: 1). The process involves evaluation of the quality of the projects, a review of expenditure and materials ${ }^{2}$, and ensuring payments are made to the beneficiaries as mandated by the scheme.

This paper aims to investigate how social audits are being conducted in Karnataka in order to provide suggestions about how to improve the design and implementation of social audits in the state. According to Jayal, "the instruments of accountability" have not been sufficiently examined in India (2008: 106) and she rightly refers to the Right to Information (RTI) as an example. However, we have chosen to focus our investigation upon social audits under MGNREGS for two reasons. First, MGNREGS is a national level scheme which if properly audited could make an immense contribution to

\footnotetext{
^ We would like to thank Australia India Insitute, University of Melbourne, for funding this research. We are grateful to two anonymous referees for their comments on an earlier draft of the paper.

* Professor, Centre for Decentralisation and Development, Institute for Social and Economic Change, Bangalore, India. Email: raja@isec.ac.in

** Honorary Senior Fellow, School of Social and Political Sciences, University of Melbourne, Australia. Email: salim@unimelb.edu.au

*** Research Officer, Centre for Decentralisation and Development, Institute for Social and Economic Change, Bangalore, India. Email: manjula@isec.ac.in
} 
participatory development and rural democratization. Second, the Gol has made a massive investment ${ }^{3}$ in the implementation of the scheme which for that reason requires some evaluation of the effectiveness of its instruments such as social audit. Finally, if social audits are effective then they will contribute to positive benefts of MGNREGS investment.

Our attempt here is rather modest since our case study focuses upon a single district in Karnataka. It therefore complements broader studies dealing with the implementation of MGNREGS in Karnataka (Pani and Iyer 2011; Kumar and Maruthi 2011; Rajasekhar et al 2012). We believe that this case study approach will provide an in-depth understanding of the relevant issues connected with the process of social audit and which will point the way for a larger investigation encompassing othe districts in the state. While there are many studies dealing with the implementation of MGNREGS, the literature on social audit under the scheme is comparatively limited barring the states of Andhra Pradesh, Rajasthan and Tamil Nadu. Social audits under MGNREGS in Tamil Nadu revealed that the scheme has resulted in major changes in the life of women (Narayanan 2008). A study on Rajasthan has highlighted that social audits have generated pressure from below to ensure that corrupt practices are brought to Ight and kept under check (Afridi 2008). However, mobilisation from below has also proved very contentious (Afridi 2008; Lakha 2011). The experience of Andhra Pradesh, however, reveals that with state government support audits can be carried out effectivey. In this state, the government has vigorously promoted auditing of the scheme through training provided to village volunteers (Aiyar and Samji 2009). These volunteers then conduct audits in villages other than their own to ensure the process is impartial Consequently, audits have identified individuals involved in the misuse of funds which have been successfully recovered (Aiyar and Samji 2009). By contrast, a study of 11 GPs in Gulbarga district (Karnataka) found that there was insufficient awareness of the scheme and audits, several implementation problems, and corruption and elite capture of the programme (PAC 2008). Our study of five GPs also revealed similar problems as those experienced in Gulbarga.

This study, which was conducted in September 2011, involved both documentary research and fieldwork in the Hiriyur taluk of Chitradurga district. The justification for selecting this district and taluk is that MGNREGS was implemented in Chitradurga from its first phase of implementation in the country. From among the six taluks in the district, we selected Hiriyur because it is neither developed nor backward but ranks average according to the D M Nanjundappa committee report (2002). After classifying GPs into two categories on the basis of whether social audits were conducted or not, we randomly selected five GPs from among those which had conducted a social audit during 2010-11.

As part of our preliminary investigation we examined both primary and secondary sources related to MGNREGS. During our field visit we examined various documents connected with social audits which included social audit reports at Chitradurga zilla panchayat office. In the five GPs, we consulted records of expenditure like receipts and payments made for works under MGNREGS. Along with GP members, we visited a few of these works which provided us with vital insights into the quality of work.

An important feature of our field visits included group discussions with members of GPs, and Vigilance and Monitoring Committees (VMCs) that are responsible for conducting social audits. Besides members of GPs, the meetings were also attended by labourers who were beneficiaries of MGNREGS. Through these meetings we were able to obtain a cross-section of views pertaining to the process of 
conducting social audits and more generally the implementation of MGNREGS. Talking to a crosssection of villagers was a useful exercise in triangulation as we were able to cross-check the evidence provided by our informants who represented diverse interest groups.

We also conducted key informant interviews both during our filed visit to Chitradurga district and in the city of Bangalore. In Bangalore we interviewed a senior official in the Rural Development and Panchayat Raj Department who was responsible specifically for MGNREGS, and a senior official of a non-government organization (NGO). We also consulted researchers who have worked on decentralization and the implementation of MGNREGS in Karnataka and other states in India.

During our visit to Chitradurga district we interviewed several key officials at the zilla panchayat who were knowledgeable about MGNREGS. Further we conducted interviews with taluk officials, including social audit coordinators and the panchayat development officers (PDOs). Through these interviews conducted at different levels of the official hierarchy, and with other individuals from a variety of backgrounds representing different and contesting interests, we were able to gain a rich insight into the challenges involved in conducting social audits under MGNREGS.

\section{How are Social Audits Conducted in Karnataka?}

The responsibility of conducting social audits in the state initially was entrusted to the State Institute of Rural Development (SIRD), Mysore (GoK n.d.). This institute was also asked to povide training to resource persons and to monitor the outcome of social audits. But, it was unable to perform the latter responsibility. From 2010-11 onwards, the task of social audit is directly coordinated by the state government.

The administrative structure adopted for social audit is at different levels. At the state level, a Social Audit Coordinator is appointed to oversee the conduct of social audits in the state. Then in each district, coordinators at the district and taluk levels are appointed and paid by the Zilla Panchayat for overseeing the social audit operations.

Committees with the responsibility of overseeing MGNREGS works and conducting social audits are formed at the village and GP levels. In each village, a VMC with nine members is formed for one year. Representatives should invariably be selected in a ward sabha (electoral constituency at the village level) meeting. Five members should be wage labourers. Guidelines state that women should have representation, although the exact number is not mentioned. At the GP level, a Social Audit Committee (SAC) is appointed for one year. Of the five members in the committee, at least onethird should have worked as wage labourers either in the previous year or current year. Members of these committees are expected to be vigilant on the extent to which the scheme is implemented as per the guidelines, and monitor different phases of its implementation. Thus the constitution of the committees is meant to be socially inclusive.

As far as the final social audit is concerned, an official deputed by the Taluk Panchayat visits the GP along with the Taluk Social Audit Coordinator. The main purpose of this visit is to ensure that the final phase of the audit conforms to the official objectives of MGNREGS which are to promote transparency and accountability. The process of social audit is quite elaborate and involves several checks. First, the officer will undertake an exercise of verification of documents along with the members 
of SAC and VMC. Second, the officer will also consider grievances expressed by the beneficiaries in so far as the process of implementation is concerned - for example complaints related to the issue of job cards, provision of employment, distance of work from the village, whether workers are from the same GP, delays in the payment of wages, etc. Third, the officer along with GP officials (elected and non elected), representatives of SAC and VMC and villagers will visit worksites to assess the quality of the work undertaken. Fourth, the report on the visit of social audit committee will be presented to the Grama Sabha, separately convened for this purpose. Finally, the social audit report will be uploaded on to the website as a measure of promoting transparency.

In the next section we provide a description of the GPs we visited and a detailed account of the social audit process. These details provide important ethnographic data and insights into the functioning of social audits.

\section{Conduct of Social Audits in the Selected Grama Panchayats ${ }^{5}$}

\section{Pastoral GP}

This GP has eight villages, 1200 households and population numbering 4,782 persons. The castewise distribution of households shows that pastoral caste of Golla, dominant caste of Vokkaliga and Scheduled Castes (SCs) are the important communities both numerically and socially, while Muslims are the minority accounting for about 5 per cent. This distribution is not, however, uniform across all the villages.

Food grains such as Ragi, Jowar and Navane (local rice) are important crops, while cash crops of onion, chillis, tobacco and cotton are widely grown in a few villages with the help of well irrigation. As far as the occupational distribution is concerned, most of the households eke out their subsistence through wage labour in agriculture. The rest of the households mainly depend on cultivation, although several of them also depend on goat/ sheep rearing especially in the villages where Gollas are the important community.

Of 19 GP members elected in May 2010, 42 per cent were women, and nearly onethird of them belonged to Scheduled Castes/ Scheduled Tribes (SC/ST) (Table 1). The castewise distribution of households across the villages is reflected in the composition of the membership of both the grama panchayat and the VMC. 
Table 1: Caste-wise (\% ) distribution of GP Members

\begin{tabular}{|c|c|c|c|c|c|c|c|}
\hline \multirow{2}{*}{$\begin{array}{l}\text { Sl. } \\
\text { No }\end{array}$} & \multirow{2}{*}{ GP Name } & \multirow{2}{*}{ Sex } & \multicolumn{5}{|c|}{ Caste } \\
\hline & & & SC & ST & OBC & General & Total \\
\hline \multirow{3}{*}{1} & \multirow{3}{*}{ Pastoral GP } & Female & 25.0 & 12.5 & 25.0 & 37.5 & $8(42.1)$ \\
\hline & & Male & 27.3 & 0.0 & 36.4 & 36.4 & $11(57.9)$ \\
\hline & & Total & 26.3 & 5.3 & 31.6 & 36.8 & $19(100.0)$ \\
\hline \multirow{3}{*}{2} & \multirow{3}{*}{ I rrigated GP } & Female & 33.3 & 16.7 & 16.7 & 33.3 & $6(35.3)$ \\
\hline & & Male & 18.2 & 0.0 & 45.5 & 36.4 & $11(64.7)$ \\
\hline & & Total & 23.5 & 5.9 & 35.3 & 35.3 & $17(100.0)$ \\
\hline \multirow{3}{*}{3} & \multirow{3}{*}{ Horticultural GP } & Female & 33.3 & 11.1 & 33.3 & 22.2 & $9(39.1)$ \\
\hline & & Male & 35.7 & 0.0 & 35.7 & 28.6 & $14(60.9)$ \\
\hline & & Total & 34.8 & 4.3 & 34.8 & 26.1 & $23(100.0)$ \\
\hline \multirow{3}{*}{4} & \multirow{3}{*}{ Border GP } & Female & 14.3 & 14.3 & 28.6 & 42.9 & $7(43.8)$ \\
\hline & & Male & 22.2 & 0.0 & 33.3 & 44.4 & $9(56.2)$ \\
\hline & & Total & 18.8 & 6.3 & 31.3 & 43.8 & $16(100.0)$ \\
\hline \multirow{3}{*}{5} & \multirow{3}{*}{ Non-irrigated GP } & Female & 14.3 & 14.3 & 28.6 & 42.9 & $7(43.8)$ \\
\hline & & Male & 22.2 & 0.0 & 33.3 & 44.4 & $9(56.2)$ \\
\hline & & Total & 18.8 & 6.3 & 31.3 & 43.8 & $16(100.0)$ \\
\hline
\end{tabular}

Source: Data collected from the five grama panchayats

Note: Figures in parentheses are column percentages.

Of 54 VMC members, about 33 per cent each belonged to SC/STs and the Golla caste. Muslim minorities constituted only 5.6 per cent of the VMC members. The remaining members $(27.8 \%)$ come from other backward caste groups. The Social Audit Committee (SAC) comprises of five members; of them, two belonged to Golla caste, one to SC and the rest belonged to other backward castes.

As per the records, the number of households obtaining MGNREGS job cards was 1,938, which was substantially higher than the actual number of households in the GP. When we enquired about this, the GP official admitted that some households possessed more than one card. The explanation given by the panchayat official is that some households, though staying together in one house, claim that they have been separated. As a result, the panchayat officials are compelled to give more than one card to some of the households.

Of those obtaining employment, 27.8 per cent belonged to SC/ST community and of 7,158 persons obtaining job cards, 38.9 per cent were women. These figures suggest that the scheme is inclusive where SC/ST population is concerned but the representation of women is somewhat low compared to its proportion in the total population. During 2010-11, 739 households worked in MGNREGS, and obtained 37,303 persondays of employment. According to the GP statistics, 32 works were completed with a total cost of Rs.31,37,772.

\section{Social Audit in Pastoral GP}

We discussed the conduct of social audits with the elected officials, VMC members, GP officials, social audit coordinators and one taluk level official. Although the GP had eight women members, only one 
was present. As has been the practice in many parts of India, husbands represented a few women elected members in the meeting. In addition, a few villagers were present though they were mere spectators.

As per the documents prepared by the GP, two rounds of meetings were conducted on J anuary 28, 2011 and June 3, 2011, respectively, for the purpose of social audit. We were informed that in the first meeting three issues were taken up: i) how to raise awareness on social audit; ii) explaining the need for the setting-up of VMC and SAC for the purpose of social audit; and, iii) provison of information on the composition of these committees. In the first meeting, VMC and SAC were constituted. During the second meeting, social audit for the year 2010-11 was presented. According to GP documentation, the GP had actively engaged in the setting up of social audit committees and by what our informants stated, the GP members were keen to promote awareness of social audits.

The panchayat officials also informed us that the villagers who were present in the social audit meeting elected VMC members. However, one man, who was supposed to be a VMC member, did not agree with the panchayat officials. In fact, surprisingly, he stated that he was not even aware of social audit! In response, the officials then maintained that it was lack of training on social audit to VMC and SAC members that had resulted in this person claiming ignorance about the existence of social audit. The officials proceeded by stressing the importance of training to members of VMCs and SACs. This episode confirmed to us that knowledge of social audit had not been sufficiently disseminated among the VMC members and the process of social audit was not yet routinised.

Out of 54 works that were completed during 2010-11, only 10 works were selected for quality inspection on the basis of two criteria: First, the works should be such that they should represent the different villages and types of works undertaken in the GP. Second, the selected works should be located close to GP headquarter village. This suggests that selection was more on the basis of convenience rather than objectively based as in the case of "unbiased" random selection!

From these 10 inspected works, we visited a water pond constructed in the village of the vice president. This pond existed even before the commencement of MGNREGS; the contribution of MGNREGS to this pond involved the strengthening of the bund with gravel. When we visited, the pond was well filled with water, and goats as well as birds were seen in the vicinity. However, the revetment work would have strengthened the bund if it had been carried out. While the pond made a useful contribution to the environment and livelihood of the villagers, there was room for improvement where its quality was concerned.

But, it appears that only the best projects are selected for social audit. On our way to the pond, a villager stopped us to enquire where we were going. When we informed him of our destination, he remarked: "why do you people always visit the projects where some work has been done? Why don't you visit those works where nothing has been done?" The comments of this villager suggest there may be disaffection among some villagers about the quality of the works under MGNREGS. The president and vice-president stated that the social audit report was presented to the villagers. They claimed none of the villagers complained about the quality of the MGNREGS works. Photos of the meeting were also shown to us. Clearly, the official version is at variance with the villager's perspective mentioned above. 
One factor that has obstructed effective social audit is the frequent turnover of social audit coordinators in Hiriyur taluk and the delay in replacing the outgoing coordinator. We were informed by the taluk official that the appointment of new social audit coordinators sometimes takes a long time because of the rule that the person selected should have undergone training at SIRD, Mysore.

The GP provided an unsigned photocopy of the social audit report for 2010-11 prepared by the social audit coordinator. Seven critical observations listed in the report included: (i) receipts for the purchase of materials were not maintained; (ii) there was wide participation of contractors in the MGNREGS works which is prohibited under the scheme; (iii) absence of people's participation in the preparation of action plans; (iv) lack of awareness about the programme; (v) villagers do not have proper information about MGNREGS programme; (vi) maintenance of documents/ files is not proper; and (vii) work boards ${ }^{7}$ had not been displayed near all the completed MGNREGS works. Interestingly, the same criticisms/ observations were also listed for the year 2009-10! These wide ranging observations are disturbing because they reveal that there are serious problems in the functioning of the scheme and the audit process is inadequate.

\section{Border GP}

This grama panchayat, bordering on Andhra Pradesh state, has five villages with 1,165 households and population of 3,752 persons. The upper caste of Vokkaliga is dominant here accounting for nearly 39 per cent of the total households, followed by SCs (22 per cent), Yadava (16 per cent), Uppara (9.4 per cent) and washer-folk ( 5 per cent). Vokkaligas are important in all the five villages, except in one village where Uppara is the dominant community. This is a predominantly agrarian GP with over 90 per cent of the households depending on agriculture. The principal occupation of about 40 per cent of the households is wage labour in agriculture, while it is cultivation for 55 per cent. The predominant crop is groundnut, while ragi, cotton, horticultural crops and onion are also grown to some extent

Of 16 elected members in this GP, nearly 44 per cent are female members - much more than one-third of reservation provided in the Constitution. Nearly 19 per cent of the members belonged to SC category. With 44.4 per cent of the members, the dominant caste of Vokkaliga controls this GP (Table $1)$.

As per the GP records, SAC and VMCs were constituted village-wise in August 2010. There were 5 members of the SAC and a total of 36 in VMCs. As can be expected, most of the members in these committees belonged to the upper caste of Vokkaliga who had a dominant status in this GP.

According to the figures provided by the GP, 24.7 per cent of households registered in MGNREGS belonged to SC/ST category. Of 988 households issued with job cards, 561 obtained work under the scheme during 2010-11. The number of workers was 1,902 and the total persondays generated during the year was 33,738 . Thus, the average number of workers from each household was about three.

During 2010-11, 74 works were listed in the action plan, but only 45 were taken up and completed. When asked for the reason, the Panchayat Development Officer (PDO) of GP explained that "action plan was prepared keeping in mind the number of job cardholders. However, the demand for 
work did not come from all the job cardholders. So, the GP could only complete the works as per the demand of work".

\section{Social Audit in Border GP}

We also elicited the information on how social audits are conducted in a meeting held at the GP office. In this meeting, seven members of GP ( 5 men and 2 women), 5 members of SAC and 8 members of VMC ( 6 men and 2 women) were present. In all, of 20 persons attending the meeting, only four were women including the GP president. She belonged to Vokkaliga caste and had 7 years of schooling. The participation of women in the meeting was very limited both in terms of numbers and their contribution to the discussion. The meeting was also attended by the taluk and district level officials.

Interestingly, the SAC and VMC members articulated very well their understanding of the social audit process. For example, they seemed to be well aware of why and how social audits are conducted. According to VMC members, their primary responsibility is to maintain the quality of MGNREGS works. They were also assigned with the responsibility of taking attendance at the worksite to monitor whether the workers/ job cardholders are present. They also checked whether workers from other GPs are employed in the work. In order to undertake these tasks, VMC members stated that, they visited the worksites twice a week. The findings of these visits are usually discussed in the monthly GP meetings; if necessary, a special GP meeting is also convened.

We were pleasantly surprised at the positive responses from VMC members on social audit process compared to other GPs. We, therefore, asked them how they had come to know of the social audit process. In response one of the men, who appeared to have considerable influence over others in the meeting, explained in English that he personally trained VMC members as he firmly believed that social audit had an important role in the implementation of MGNREGS. He, therefore, got elected to SAC. We also learnt that he was the ex-president of the Grama Panchayat. By profession, he was an engineer and after retirement was taking care of his agricultural property.

Mr. Engineer, as we prefer to call him, added that when SAC and VMCs were formed, everyone was informed that the members of these committees would be given training on social audit. He complained that no training had been given to any VMC member from the panchayat. According to him there was still a need to provide training on technical aspects of social audit, and he asked the officials present in the GP meeting that such training should be provided at the GP level.

With pride, VMC members stated that a work board had been displayed near all the 45 completed MGNREGS works. They claimed that no machinery was deployed as the problem of unemployment was severe in the locality, and that several labourers are willing to work. Only skilled labourers, if at all required, were allowed from the neighbouring GP but not unskilled workers. When we asked those attending the meeting why this GP is different compared to the others, Mr. Engineer claimed that the migration from the GP is very high and poor people are in need of MGNREGS work. He also added that MGNREGS wages are relatively high in the slack season when the female wages in agricultural work drastically decline, thus providing an incentive to take up the work provided by the scheme. 
Though the above evidence suggests that this is a vibrant GP where members of VMC are well aware of social audits, that they have actively participated in the process of social audit, and that they have been striving to ensure the accountability, the Social Audit report presented on May 15, 2011 in the GP provided a different picture altogether. Four observations were made in the report: a) A majority of the works were undertaken by Contractors; b) People's participation in the preparation of action plan was missing; c) There were no awareness campaigns for the people in the GP; and d) No proper information was disseminated among the people.

This led us to explore the issue further. Our search of records and further discussions revealed that Mr. Engineer who is Vokkaliga by caste and an elite member of the GP had captured the entire audit process. First, he handpicked a few persons and ensured thatthey were elected as VMC members. Second, he made sure that his supporters obtained benefits from the scheme. Several of them obtained MGNREGS funds to undertake private works on fields belonging to them or their relatives. Mr. Engineer himself obtained funds to undertake work on his land. All of them had job cards, showed that their household members had worked for about 100 days and each obtained amounts close to Rs. 10,000. But judging by their appearance such as the clothes and jewellery that they were wearing, most of them did not look like workers engaged in unskilled work. When we asked them whether they really worked as labourers, Mr. Engineer stated that although he was wearing a pair of trousers for the meeting, he would transform himself as a worker at home!

All the while, the female President was silent. Our lady colleague asked for her opinion on social audits and how they were conducted in the jurisdiction of GP. Even before she could respond, Mr. Engineer interjected and stated "why do you ask her. She is illiterate and she does not know what to say". Evidently, seven years of schooling and sharing the same caste did not mean anything to him! She continued to be silent for the rest of the meeting. His dismissive attitude towards her derived fromhis much higher education status and the fact that he was an elite male member of the village.

\section{I rrigated GP}

This GP consists of 7 villages with a population of 5,680 and the number of households is 1,361 . The predominant castes are Vokkaliga, Golla and Kuruba. Most of the households eke out their subsistence through wage labour work.

In all, 17 persons were elected to the GP in May 2010. Of them, 35.3 per cent were women members. The proportion of women representatives in this GP is the lowest compared $b$ our other sample GPs in Chitradurga. Nearly 30 per cent of the GP members were elected through SC/ST reservation (Table 1). There were 63 VMC members representing 7 villages. Expectedly, nearly 67 per cent represent the numerically dominants castes such as Vokkaliga, Golla and Kuruba. About 27 per cent of VMC members belonged to SCS/ STs.

For the year 2010-11, 1,092 households had registered for MGNREGS and had obtained job cards. Of them, 24 per cent belonged to SC community, 7 per cent to ST and the rest to other communities. With over one-third of the beneficiaries belonging to SC/ST communities, the scheme is socially inclusive. 
During 2010-11, 43 works were completed at a total cost of Rs.37.92 lakhs. We were informed that 3,638 workers from 953 households worked in these 43 works, thus, generating 22,702 of persondays during 2010-11. Though 120 works were listed in the action plan, the panchayat could take up only 43 because of problems relating funds release.

\section{Social Audit in I rrigated GP}

A lively discussion on the process of conducting social audit was held with a large number of persons attending the meeting held at the GP office. In all, about 30 persons attended the meeting; most of these were the elected leaders of GP, members of VMC, contractors, landlords, cultivators and labourers. Of the 17 GP members, only eight GP members (including four women GP members) attended.

A grama sabha meeting was organised on May $23^{\text {rd }} 2011$ where there were seven agenda points. One of them was the presentation of social audit report; thus, implying lesser importance to social audit in grama sabha proceedings. We were briefed that the following issues were raised in this meeting:

- The wages of Rs.125 paid under MGNREGS are low. Because of this the labourers were unwilling to take part in MGNREGS works. Even if workers took part, the quantum of work undertaken by them would normally be less. When VMC members point this out, the workers' response is that this is all what they can do for Rs. 125 !

- The low wages also resulted in lack of interest among workers which led them to adopt 'foot dragging techniques' like, for example, they did not report to work on time. If they were questioned, the typical response was "why are you bothered? Are you paying us from your own pocket?"

- Though wages have to be paid once a week, payment of wages is delayed. This also contributes to the unwillingness by workers to work under MGNREGS.

What is evident is that wage differentials between job markets are an important influence over commitment to working in the scheme. Worker resistance is not just confined to 'foot-dragging techniques' but also includes challenging the orders of those charged with the functions of implementation of the scheme.

Another important finding from the meeting was that contractors were perceived as essential in the implementation of MGNREGS works even though they are prohibited under the scheme. Their involvement was viewed as necessary for several reasons. First, because the implementation of projects under the scheme requires persons with considerable experience of supervision of labourers, measurement of work completed, getting the work done, etc., only those with the necessary experience will come forward to implement MGNREGS works. The GP on its own does not have the time to get these works implemented. Second, there is no system of advance payment for the implementation of MGNREGS works. As a result, it is difficult for the GP to raise the money required for the implementation of the works, payment of wages to labourers within the stipulated time, payment to those who provide materials like sand, cement, etc, and transportation services. Only the contractors 
have the resources for these requirements. Third, there is an element of risk in the implementation of MGNREGS works. Given that natural resource management works (which usually involve earth work) have to be given prominence under the scheme, it is not always certain whether the bill for the works undertaken would be cleared by the government or not. Because of these reasons, we were informed in the meeting that only contractors have been taking up the implementation of MGNREGS works in the GP. Their sole interest in this is to gain a certain percentage of expenditure as income for themselves. Members of GP and VMC, who were present in the meeting, did not see use of contractors as a problem given the inherent risk in getting the bills of MGNREGS works sanctioned by government officials.

VMC members informed us that they visited the worksite to check the quality of the works. When we asked members of GP and VMC whether these visits would have the desired impact on quality or not, they noted that 'the impact is only limited'. They argued that because of social auditing (especially involvement of VMC members), the profit margin of the contractor would come down to 15-20 per cent. Otherwise, the profit margins would hover around 40 per cent.

Considering the above limitations and factors one may ask: What has been the impact of MGNREGS? One significant concern arising from the implementation of the scheme was voiced by a person, who introduced himself as Zamindar but was not a GP member. He claimed that he owns around 100 acres of land, most of which is irrigated. The Zamindar complained that because of MGNREGS there is a high demand for labourers. The employers have to not only pay higher wages but also to appease labourers with all kinds of benefits such as transport allowance, serving of tea/ food, etc. According to the Zamindar, with farming becoming increasingly unviable on account of rising input costs, lack of support prices and marketing problems, these additional costs would make farming even less viable. The other farmers present in the meeting readily agreed with the Zamindar.

GP members, mostly cultivators, were also against MGNREGS. According to them, MGNREGS projects do not result in any permanent or tangible assets as most of them are in the nature of earth works. Because of the programme, the elected leaders are under pressure from the people as wel as officials to undertake works that would result in tangible assets.

But, when we posed this question to a few wage labourers present in the meeting, the response was quite different. The wage labourers clearly acknowledged the fact that the programme benefited them and they could earn additional wage income ranging between Rs.3,000 - 4,000 in a year. Thus, what emerged from the meeting was that there are differing perceptions on MGNREGS depending upon occupational status and the benefits derived from the scheme.

Other problems were also mentioned in the meeting. Although the action plan is prepared and sent to the Zilla Panchayat early, there is enormous delay in the issue of sanctioning the work. According to GP members, the work is usually sanctioned around December of the year. With only three months of the financial year left to implement the MGNREGS projects and utilise the sanctioned amount, the GPs have to go through considerable stress and strain.

In the meeting, we found out that all the elected representatives possessed job cards. When we asked whether all the GP member households depend on unskilled wage work, there was a counter question posed to us: "is it wrong if GP members have job cards?". They added that even the PDO had advised them not to have job cards. It was also revealed during the discussion that most of the persons 
present in the meeting, including the Zamindar and VMC members, had a job card. We were informed that job card had been obtained in the hope that this would help them to avail of government benefits in future. It turned out that VMC and GP members, who had job cards, each obtained wage amounts close to Rs. 10,000 during 2010-11! Job cards are therefore prized both for the current income they provide and their future value in the form of anticipated government benefits.

\section{Non- I rrigated GP}

With five villages, this GP has 1,487 households. The two dominant castes in the panchayats are Vokkaliga and Gollas. Most of the households depend on wage labour in agriculture and cultivation. Commercial crops such as groundnut, onion, sunflower, cotton are important in the panchayat.

The total number of GP members is 16 (seven women and nine men). About 25 per cent of them belonged to SC/ST category, 31 per cent to other backward castes such as Gollas and 44 per cent to Vokkaliga and Lingayath. Thus, a significant proportion of the GP members belonged to upper or dominant castes. Apart from five SAC members, there were 44 VMC members representing five villages. All the SAC members were job cardholders.

According to GP statistics, 825 households worked during 2010-11 and obtained 34,621 persondays of employment. It was stated that 57 works were completed during 2010-11 with expenditure of Rs.93.74 lakhs.

\section{Social Audit in Non-I rrigated GP}

In all, 26 persons attended the meeting organised for us to find out the process of social audits. But, only one SAC member and two VMC members attended. There were six GP members (including President) in the meeting. One of the GP members, producing considerable output of onions under well irrigation, was referred to as 'onion king' by the villagers attending the meeting. From his participation in the meeting and the respect accorded to him, he appeared to hold high status in the village community. There was proxy representation of husband in one of the cases of women GP member. None of the women members attended the meeting because, as explained by male members, they were busy with the local festival. Barring two wage labourers, most of the remaining people were cultivators.

Interestingly, excepting two people, all the persons who were present in the meeting held job cards. Almost all of them claimed to have worked in MGNREGS for about 90 days and obtained about Rs. 10,000 each.

We decided to undertake a visit to one of the worksites. Accordingly, we were taken to a check dam, which was constructed on private land belonging to vokkaliga farmer at a substantial cost of about Rs.3.80 lakhs. The check dam appeared to have been constructed well with proper dignment of boulders. In the records, it was shown that a new bund connecting to the check dam was also constructed. However, the bund was not new. There was a bund even before MGNREGS; the height was merely raised by a few feet as part of this work! It appeared to us that what is recorded in a social audit report does not correspond to reality. Thus proper inspection and measurement of works is 
necessary to ensure that exaggerated claims for expenditure are not being made for private gain to contractors and other vested interests.

\section{Horticultural GP}

There are seven villages with a total population of 13,034. According to the figures provided by the GP, the SC/ST population was 59.3 per cent of the total population. Thus numerically this GP is dominated by $\mathrm{SCS} / \mathrm{STS}$.

The total number of households is 2,961. Of them, 1,321 households had registered for MGNREGS and obtained the job cards. But the number of households demanding work during 2010-11 was only 805 . They obtained a total of 31,978 persondays of employment. Of 86 works that were included in the action plan, only 71 were undertaken and completed.

The grama panchayat has 23 elected members; of whom, 9 are women and 14 are men. About 39 per cent of the elected members belonged to SC/ST community. The proportion of SC/ST elected members to total was the highest in this GP as compared to the other four selected GPs. This is understandable, as the SC/ST population in this GP forms a significant proportion of the total population.

One each of five SAC members belonged to Muslim, Goundar, Bhovi and Golla and ST communities and all of them possessed job cards. In all, there were 27 VMC members. During 2010-11, the total expenditure incurred for MGNREGS was Rs. 57.83 lakhs.

\section{Social Audit in Horticultural GP}

A detailed discussion on the process of social audit could not be held in this GP as that day was the last date for filing of nominations for the re-election of a GP member. We, however, managed to speak to some officials and GP members, SAC and VMC members.

According to our informants 16 works were selected for social audit inspection out of the 71 works that were completed during 2010-11. A grama sabha meeting was held on 23/6/2011 and the social audit report for the 2010-11 was presented. Apparently, in the same meeting the social audit report for the previous year 2009-10 was also presented! Observations made in the social audit report prepared by the taluk coordinator of social audit were as follows:

- All the 71 works were undertaken at the place mentioned in the action plan;

- Only minor problems were found in the documentation but not any major lapses;

- Lack of awareness about the scheme among the people was noted;

- Lack of proper monitoring and supervision from the concerned officials was observed;

- Absence of citizens in the preparation of action plan was evident;

- During the process of programme implementation, several rules and regulations were not followed; and

- For the proof of payment, details such as NMR number, demand draft or cheque number and date were not recorded in the measurement book $(\mathrm{MB})^{10}$. 
The findings of the report therefore indicated that the social audit had identified wideranging lapses in the implementation of MGNREGS works. However, the follow-up on these lapses was missing because the social audit coordinators only submitted the file to the higher level authorities (Executive Officer and Chief Executive Officer). Taking up of action is something which was left to them.

We were also proudly informed that this GP was short-listed as one of the best based on the overall performance in MGNREGS including the conduct of social audit. The women workers from this GP and neighbouring GPs who had completed 100 days of employment in MGNREGS works were chosen for a trip to Delhi for a national meeting of the MGNREGS workers organised by central government and presided over by Smt. Sonia Gandhi. We spoke to one lady who had visited Delhi to attend the meeting. This lady was, obviously, quite excited about the whole experience and was thankful to the programme for providing her with 100 days of employment, which won her the trip to Delhi. She was also one of the VMC members and turned out to be the wife of one of the panchayat officials. Thus she was wellconnected and not just an ordinary labouring villager.

One VMC member candidly stated that he was involved in the supervision of the MGNREGS works and for the time and effort he expended, he needed to be compensated monetarily. He was accordingly compensated and in the record of expenditures it was shown that he had worked and was paid. Apparently, this was a common practice. In fact, he justified this practice on the grounds that it would create some monetary incentive for VMC or SAC members, otherwise they would be deprived of any payment or honorarium for their efforts.

According to our informants some of the VMC members also got some private work done on their own land. This raises an interesting and significant question: Who audits the works undertaken on lands belonging to members of the auditing committee? This was not clearly explained to us. If it is the same VMC members who had work done on their lands then it could potentially compromise the audit process.

\section{Conclusions and Policy Suggestions}

It is evident from our case study that the social audit process in the GPs we visited was marked by many constraints and problems. While all the GPs conducted social audits their capacity to undertake audits effectively was compromised by the influence wielded by village elites like Mr. Engineer, the Zamindar and the 'onion king'.

Significantly there was a structural conflict of interest between cultivators who employed agricultural labour and the labourers who were seeking additional work under MGNREGS to supplement their income. The cultivators complained that the scheme created shortages of labour and raised wages $^{11}$ whereas the labourers demanded more work under the scheme. In our view, the implementation of the scheme and the process of social audit has to be considered in the context of this structural conflict. The dominant actors in this structural relationship like the ones mentioned above have an influential status in local institutions connected with social audits.

Some of the key problems ${ }^{12}$ and complaints we identified with the social audits included:

- Lack of participation of women

- Selective audit of works 
- Relative ineffectiveness of the VMCs

- Lack of independent auditors

- Inadequate training provided to villagers for conducting social audits

- Insufficient scrutiny of the possession and distribution of job cards

- Complaints by labourers that not enough work was available under MGNREGS

It was very evident that women are not active participants in PRIs. They do have representation in GPs, but do not have an independent voice. This is anomalous considering that many of the beneficiaries of the scheme are women. Strategies need to be put in place that will involve women in more active participation and decision making in various committees including VMCs. One strategy to achieve this objective may be to involve women's Self-Help Groups (SHGs) at the local level to mobilize and motivate women to participate more actively in PRIs. As part of this strategy it may even be necessary to engage men in participatory exercises to 'educate' them of the benefits of women's participation.

The inspection of projects under MGNREGS is not satisfactory and requires broader coverage. We were informed in one GP that projects in close proximity are the ones that are inspected, but those farther away are not inspected. If that is the case then not sufficient attention is paid to checking the quality of projects across the board. In the interest of quality and enhancing agricultural productivity it is essential that all projects are adequately inspected.

It was clear from our discussions with GP members and VMC members that the beneficiaries of the scheme (i.e. the workers in MGNREGS) are not actively and substantially involved in social auditing. Although it has been maintained that the selection process is democratic and takes pace in the grama sabha meeting, we did not find evidence that this has been the case. There was nothing to suggest that GP officials and social audit coordinators felt that the membership of VMCs needed to be scrutinized and representation of the beneficiaries on VMCs should be increased. There was no attempt to question the selection/appointment to VMCs. The membership of VMCs was skewed in favour of the betteroff people in the villages, some of whom are large farmers or those who own sufficient land for commercial agriculture. This membership composition does not promote impartial social auditing. The involvement of external civil society actors like NGOs and others may be necessary to facilitate impartial audits.

The revised social audit guidelines (2011) released by the Ministry of Rural Development at the Centre recognize the need for impartial auditing. Accordingly the guidelines recommend that the social audit process should be "independent of any process undertaken by the implementing agency of the scheme" (MoRD 2011). Further, the guidelines require the State Government to set up an "independent organization" called Social Audit Unit whose role will be to assist the Grama Sabhas in conducting social audits. The Grama Sabhas will be aided by resourcepersons employed by the Social Audit Unit.

Together they will engage in checking muster rolls, works undertaken under the scheme and various documents related to expenditure of funds. Importantly, the resource persons will not engage in conducting audits in panchayats where they reside in order to ensure they are not susceptible to pressure from residents in their own panchayats. This is in keeping with the experience of Andhra Pradesh where trained village volunteers conduct audits in villages other than their own. 
With the introduction of new guidelines the VMCs have now been superseded at least in theory. During our research the VMCs were still in place and functional. An independent organisation to conduct social audits is yet to be set up at the state level. Even now, in practice, VMCs still exist and their phasing out, it appears, will be a gradual process.

If social audits are to be effective then it is necessary to provide appropriate awareness to Grama Sabha members. During our study there was little evidence of such awareness raising or training for GP or VMC members. Though claims were made by individuals like Mr. Engineer that they were engaged in training VMC members we were not provided with evidence to verify that. The new social audit guidelines however recognize the need for capacity building and make provision for it through the Social Audit Unit.

The allocation and utilization of job cards requires closer scrutiny. The scheme is based upon self-targeting so anyone can obtain a job card provided they are willing to do manual work. We found everyone, including large farmers and GP members, possessed a job card. But, what exactly are they doing with the job cards? Are they working on MGNREGS works? Or are they just storing them? Or are they lending their job cards for short term gains? Most of the GP and VMC members have received close to Rs. 10,000 as MGNREGS wages implying that they have worked for almost 100 days! This is interesting given that the proportion of workers obtaining 100 days of employment is less than half in India as a whole. The utilization of job cards thus requires some investigation.

Though lot of people possessed job cards not everyone who wanted work could be offered work. Several reasons were stated for this predicament. First, the delay in the release of funds from state and central governments limits the amount of work being made available. A more timely release of funds would assist in creating more jobs ${ }^{13}$. Second reason for the limited availability of work is because the work clashes with the busy agricultural seasons causing shortage of labour. There is therefore more need for synchronization between the release of work on MGNREGS and the demand for labour during agricultural seasons. There were also complaints from farmers about MGNREGS raising the wage rates. From aur discussions at GPs it appeared that the opinion was divided over the link between MGNREGS and higher wage rates. The division of opinion was to some extent along class lines where the cultivators affirmed the link and the labourers questioned it.

The process for selecting projects also needs to be examined and streamlined. We were informed in one GP that the selection of projects depended upon who 'shouted the loudest'. If that is the case then the selection of projects is not based upon merit but elite influence. There should be clear procedures for selection of projects and checks and balances to ensure that project selection is not conducted on an ad hoc basis or swayed by influence.

We believe the policy suggestions made above could make social auditing more effective and enhance the contribution of MGNREGS to the local economy. In our opinion, the revised guidelines will go some way to overcoming the limitations of social auditing that we have identified in this study. In particular, capacity building of beneficiaries through training and deploying independent resource persons will counteract to some degree the influence wielded by the village elites. If social audit is to contribute to transparency and accountability then it is essential that audits are conducted in an 
impartial manner without interference from village elites and other vested interests but with active participation of genuine beneficiaries.

\section{Notes}

1 MGNREGS is a rights based scheme that offers 100 days of guaranteed employment to anyone in rural areas willing to undertake manual labour on infrastructure projects. The implementation of the scheme has been extensively reviewed (Khera 2011, MoRD 2012 and Berg et al 2012). We do not intend to repeat the same exercise here.

260 per cent of the expenditure is on wages, while 40 per cent is on material.

3 The total expenditure incurred on MGNREGS during the period 2008-09 to 2011-12 was Rs. 142,175 crores.

4 It may be noted that this committee does not exist anymore since last year.

5 We have named GPs according to their primary agricultural feature and location in order to maintain confidentiality and protect the identity of our informants.

$6 \quad$ Out of 82 works that were listed in the action plan, only 32 works were completed. Reasons attributed for not completing the remaining 50 works are the following. First, the demand for work was less. Second, the actual work was started in the month of November and had to be completed before the completion of financial year. So, due to paucity of time, all the works were not undetaken.

7 Work boards, which are placed near the completed works, provide information on the starting date, work description, total expenditure, etc.

8 It should be noted that this was contrary to the position taken by the PDO that lack of demand resulted in not starting a large number of works in the GP. This was also contrary to the position taken in the other GPs where the demand for MGNREGS work was stated to be low because of unwillingness on the part of workers to work at wages provided in the scheme which are much lower than the market rate for agricultural labour.

9 Works such as earthen bunding, desilting of tanks, channels, etc., may get washed out even if the work was completed. Consequently, it becomes difficult to convince the officials that the work was infact done.

10 The Measurement Book provides the technical details of the works undertaken.

11 Rigorous empirical studies on the impact of MGNREGS on employment generation and wages, based on nationwide data, show that the scheme has had a positive impact on the labour market. Berg et al (2012), using Agricultural Wages in India data on month- and district wise agricultural wages for 19 major states in India for the period 2000-2011, find that MGNREGS has led to a 5.3 per cent increase in the real agricultural wages. Imbart and Papp (2012), using NSSO data, show that public employment increased by 0.3 days per prime aged person per month after the introduction of MGNREGS, especially in those districts where the scheme was introduced during the first phase. Azam (2012) shows that MGNREGS has had a positive impact on labour market outcomes, especially women's labour market participation and wages.

12 Large size of the GPs together with distant location of villages from the GP headquarters may be a hindrance to the successful conduct of social audit.

13 This was however not accepted by the officials.

\section{References}

Afridi, F (2008). Can Community Monitoring Improve the Accountability of Public Officials? Economic and Political Weekly, 43 (42): 35-40.

Aiyar, Yamini and S Samji (2009). Transparency and Accountability in NREGA. A Case Study of Andhra Pradesh. In Al Working Paper No. 1, (pp. 1-28). New Delhi: Accountability Initiative, Centre for Policy Research.

Azam, Mehtabul (2012). The Impact of Indian J ob Guarantee Scheme on Labor Market Outcomes: Evidence from a Natural Experiment. Discussion Paper No. 6548. IZA: Berlin, Germany, May. 
Berg, Erlend, Sambit Bhattacharya, D Rajasekhar and R Manjula (2012). Can Rural Public Works Affect Agricultural Wages? Evidence from India. CSAE Working Paper Number 2012-05, University of Oxford.

CAG (2010). Office of Comptroller and Auditor General of India. Report of the Task Group on Social Audit, (Jan. 2010), p. 3 [social_audit_task_group_report_2010.pdf, accessed on 1 Dec. 2011].

GoK (n.d.). Draft Concept Note on the Social Audit Mechanisms to be followed in Karnataka. www.karnregs.kar.nic.in. Accessed on November 16, 2012.

Imbert, Clément and John Papp (2012). Equilibrium Distributional Impacts of Government Employment Programs: Evidence from India's Employment Guarantee Unpublished Manuscript, March.

Jayal, Niraja Gopal (2008). New directions in theorizing social accountability?. IDS Bulletin, 38 (6): 1059.

Khera, Reetika (ed) (2011). The Battle for Employment Guarantee New Delhi: Oxford University Press.

Kumar, Parmod and I Maruthi (2011). Impact of NREGA on Wage Rate Food Security and Rural Urban Migration in Karnataka. Bangalore: Agricultural Development and Rural Transformation Centre, Institute for Social and Economic Change, mimeo.

Lakha, Salim (2011). Accountability from Below: The Experience of MGNREGA in Rajasthan (India). Asia Research Institute Working Paper Series No.171. National University of Singapore. http://www.ari.nus.edu.sg/docs/wps/wps11_171.pdf. Accessed on November 16, 2012

MoRD (2011). The Gazette of India: Extraordinary. Ministry of Rural Development Notification, Part II Sec. 3 (i), 30th June.

MoRD (2012). MGNREGA Sameeksha: An Anthology of Research Studies on the Mahatma Gandhi National Rural Employment Guarantee Act, 2005 - 2006-12. New Delhi: Orient Black Swan.

Nanjundappa, D M (2002). Report of the High Power Committee for Redressal of Regional Imbalances in Karnataka. Bangalore: Government of Karnataka.

Narayanan, Sudha (2008). Employment Guarantee, Women's Work and Childcare Economic and Political Weekly, XLIII (9): 10-13.

PAC (2008). Pilot Social Audit of MGNREGA in Gulbarga District, Karnataka. Bangalore: Public Affairs Centre, mimeo, http://www.pacindia.org, accessed on 7 May 2010.

Pani, N and C G Iyer (2011). Evaluation of the Impact of Processes in the Mahatma Gandhi National Rural Employment Guarantee Scheme in Karnataka. Bangalore: National Institute of Advance Studies.

Rajasekhar, D, M Devendra Babu and R Manjula (2012). Elite Capture in Grama Panchayats of Karnataka. Bangalore: Institute for Social and Economic Change, mimeo.

Singh, Shekhar and S Rajakutty (2007). Social Audit: A Peoples Manual Hyderabad: National Institute of Rural Development. http://nrega.nic.in/so_audit.htmAccessed on November 3, 2012. 


\section{Recent Working Papers}

233 History Revisited: Narratives on Politica and Constitutional Changes in Kashmir (1947-1990)

Khalid Wasim Hassan

234 Spatial Heterogeneity and Population Mobility in India

J ajati Keshari Parida and S Madheswaran

235 Measuring Energy Use Efficiency in Presence of Undesirable Output: An Application of Data Envelopment Analysis (DEA) to I ndian Cement I ndustry Sabuj Kumar Mandal and S Madheswaran

236 Increasing trend in Caesarean Section Delivery in India: Role of Medicalisation of Maternal Health

Sancheetha Ghosh

237 Migration of Kashmiri Pandits: Kashmiriyat Challenged? Khalid Wasim Hassan

238 Causality Between Energy Consumption and Output Growth in Indian Cement Industry: An Application of Panel Vector Error Correction Model Sabuj Kumar Mandal and SMadheswaran

239 Conflict Over Worship:A Study of the Sri Guru Dattatreya Swami Bababudhan Dargah in South India Sudha Sitharaman

240 Living Arrangement Preferences of the Elderly in Orissa, India Akshaya Kumar Panigrahi

241 Challenges and Pospects in the Measurement of Trade in Services Krushna Mohan Pattanaik

242 Dalit Movement and Emergence of the Bahujan Samaj Party in Uttar Pradesh: Politics and Priorities Shyam Singh

243 Globalisation, Democratic Decentralisation and Social Secutiry in India

S N Sangita and T KJ yothi

244 Health, Labour Supply and Wages: A Critical Review of Literature Amrita Ghatak

245 Is Young Maternal Age A Risk Factor for Sexually Transmitted Diseases and Anemia in I ndia? An Examination in Urban and Rural Areas Kavitha N

246 Patterns and Determinants of Female Migration in India: Insights from Census Sandhya Rani Mahapatro

247 Spillover Effects from Multinational Corporations: Evidence From West Bengal Engineering I ndustries Rajdeep Singha and K Gayithri

248 Effectiveness of SEZs Over EPZs Structure: The Performance at Aggregate Level Malini L Tantri

249 Income, Income Inequality and Mortality An empirical investigation of the relationship in I ndia, 1971-2003 K S J ames and T S Syamala
250 Institutions and their I nteractions: An Economic Analysis of I rrigation Institutions in the Malaprabha Dam Project Area, Karnataka, I ndia Durba Biswas and L Venkatachalam

251 Performance of I ndian SEZs: A Disaggregated Level Analysis Malini L Tantri

252 Banking Sector Reforms and NPA: A study of I ndian Commercial Banks Meenakshi Rajeev and H P Mahesh

253 Government Policy and Performance: A Study of I ndian Engineering I ndustry Rajdeep Singha and K Gayithri

254 Reproduction of Institutions through People's Practices: Evidences from a Gram Panchayat in Kerala Rajesh K

255 Survival and Resilience of Two Village Communities in Coastal Orissa: A Comparative Study of Coping with Disasters Priya Gupta

256 Engineering I ndustry, Corporate Ownership and Development: Are I ndian Firms Catching up with the Global Standard? Rajdeep Singha and K Gayithri

257 Scheduled Castes, Legitimacy and Local Governance: Continuing Social Exclusion in Panchayats Anand I nbanathan and N Sivanna

258 Plant-Biodiversity Conservation in Academic Institutions: An Efficient Approach for Conserving Biodiversity Across Ecological Regions in I ndia Sunil Nautiyal

259 WTO and Agricultural Policy in Karnataka Malini L Tantri and R S Deshpande

260 Tibetans in Bylakuppe: Political and Legal Status and Settlement Experiences TungaTarodi

261 Trajectories of China's I ntegration with the World Economy through SEZs: A Study on Shenzhen SEZ Malnil L Tantri

262 Governance Reforms in Power Sector: Initiatives and Outcomes in Orissa Bikash Chandra Dash and S N Sangita

263 Conflicting Truths and Contrasting Realities: Are Official Statistics on Agrarian Change Reliable? VAnil Kumar

264 Food Security in Maharashtra: Regional Dimensions Nitin Tagade

265 Total Factor Productivity Growth and I ts Determinants in Karnataka Agriculture Elumalai Kannan

266 Revisiting Home: Tibetan Refugees, Perceptions of Home (Land) and Politics of Return Tarodi Tunga 
267 Nature and Dimension of Farmers' Indebtedness in India and Karnataka Meenakshi Rajeev and B P Vani

268 Civil Society Organisations and Elementary Education Delivery in Madhya Pradesh Reetika Sya

269 Burden of Income Loss due to Ailment in India: Evidence from NSS Data Amrita Ghatak and S Madheswaran

270 Progressive Lending as a Dynamic Incentive Mechanism in Microfinance Group Lending Programmes: Empirical Evidence from I ndia

Naveen Kumar K and Veerashekharappa

271 Decentralisation and Interventions in Health Sector: A Critical I nquiry into the Experience of Local Self Governments in Keral

M Benson Thomas and K Rajesh

272 Determinants of Migration and Remittance in India: Empirical Evidence J ajati Keshari Parida and S Madheswaran

273 Repayment of Short Term Loans in the Formal Credit Market: The Role of Accessibility to Credit from I nformal Sources Manojit Bhattacharjee and Meenkashi Rajeev

274 Special Economic Zones in I ndia: Are these Enclaves Efficient? Malini L Tantri

275 An Investigation into the Pattern of Delayed Marriage in I ndia Baishali Goswami

276 Analysis of Trends in I ndia's Agricultural Growth Elumalai Kannan and Sujata Sundaram

277 Climate Change, Agriculture, Poverty and Livelihoods: A Status Report K N Ninan and Satyasiba Bedamatta

278 District Level NRHM Funds Flow and Expenditure: Sub National Evidence from the State of Karnataka K Gayithri

279 In-stream Water Flows: A Perspective from Downstream Environmental Requirements in Tungabhadra River Basin

K Lenin Babu and B K Harish Kumara
280 Food I nsecurity in Tribal Regions of Maharashtra: Explaining Differentials between the Tribal and Non-Tribal Communities Nitin Tagade

281 Higher Wages, Cost of Separation and Seasonal Migration in I ndia J ajati Keshari Parida and S Madheswaran

282 Pattern of Mortality Changes in Kerala: Are they Moving to the Advanced Stage? M Benson Thomas and K S J ames

283 Civil Society and Policy Advocacy in India V Anil Kumar

284 I nfertility in I ndia: Levels, Trends, Determinants and Consequences T S Syamala

285 Double Burden of Malnutrition in I ndia: An Investigation Angan Sengupta and T S Syamala

286 Vocational Education and Child Labour in Bidar, Karnataka, I ndia V Anil Kumar

287 Politics and Public Policies: Politics of Human Development in Uttar Pradesh, India Shyam Singh and V Anil Kumar

288 Understanding the Fiscal I mplications of SEZs in I ndia: An Exploration in Resource Cost Approach Malini L Tantri

289 Does Higher Economic Growth Reduce Poverty and I ncrease I nequality? Evidence from Urban India Sabyasachi Tripathi

290 Fiscal Devaluations Emmanuel Farhi, Gita Gopinath and Oleg Itskhoki

291 Living Arrangement Preferences and Health of the Institutionalised Elderly in Odisha

Akshaya Kumar Panigrahi and T S Syamala

292 Do Large Agglomerations Lead to Economic Growth? Evidence from Urban India Sabyasachi Tripathi

293 Representation and Executive Functions of Women Presidents and Representatives in the Grama Panchayats of Karnataka Anand Inbanathan

Price: Rs. 30.00

ISBN 978-81-7791-150-3

\section{InSTITUTE For Social AND ECONOMIC CHANGE}

Dr V K R V Rao Road, Nagarabhavi P.O., Bangalore - 560 072, India

Phone: 0091-80-23215468, 23215519, 23215592; Fax: 0091-80-23217008

E-mail: lekha@isec.ac.in; Web: www.isec.ac.in 